\title{
Protecting the Public Interest: Nonstatutory Suits by the United States
}

In a series of cases decided during the last century, the Supreme Court recognized the standing of the United States, with or without statutory authority, to sue to protect the public interest. ${ }^{1}$ By implication, the Court located the authority to claim United States standing in the national executive. ${ }^{2}$

Despite these precedents and subsequent cases decided on their authority, recent lower court decisions have refused to allow suits by the United States that are not explicitly authorized by legislation. ${ }^{3}$ This denial of nonstatutory executive standing has caused the constitutional rights of some individuals to go unasserted. ${ }^{4}$ Restricting

1. See, e.g., In re Debs, 158 U.S. 564, 586 (1895) (United States has nonstatutory standing to seek injunction to protect public from obstruction of interstate commerce); United States v. American Bell Tel. Co., 128 U.S. 315, 367 (1888) (obligation to protect public forms essence of right of United States to bring suit for patent fraud); United States v. San Jacinto Tin Co., 125 U.S. 273, 285-86 (1888) (standing to sue to reclaim land procured by fraud on General Lands Office supportable on basis of obligation of United States to protect public).

2. None of the early cases explicitly addressed the question of the executive's right to claim nonstatutory government standing. Yet, by upholding claims of standing asserted by the executive without congressional authorization, Supreme Court decisions in United States v. American Bell Tel. Co., 128 U.S. 315 (1888), and especially in In re Debs, 158 U.S. 564 (1895), permitted the inference that independent authority to claim standing on behalf of the United States resided in the executive branch. See, e.g., United States v. Brand Jewelers, Inc., 318 F. Supp. 1293, 1297, 1300 (S.D.N.Y. 1970) (drawing inference); Note, Nonstatutory Executive Authority to Bring Suit, 85 HARv. L. REv. 1566, 1569 (1972) ( $D e b s$ advanced concept of independent executive power to vindicate constitutional objectives).

3. See, e.g., United States v. Solomon, 419 F. Supp. 358 (D. Md. 1976), aff'd, 563 F.2d 1121 (4th Cir. 1977); United States v. Mattson, C.A. No. 74-138-BU (D. Mont. Sept. 28, 1976), aff'd, 600 F.2d 1295 (9th Cir. 1979).

4. Among the people most likely to suffer are mental patients, such as those whose rights the United States was denied standing to assert in two recent cases. See United States v. Solomon, 419 F. Supp. 358 (D. Md. 1976), aff'd, 563 F.2d 1121 (4th Cir. 1977); United States v. Mattson, C.A. No. 74-138-BU (D. Mont. Sept. 28, 1976), aff'd, 600 F.2d 1295 (9th Cir. 1979). Because of their handicaps and restricted circumstances, mental patients are frequently unable to bring suits on their own behalf. See Comment, Wyatt v. Stickney and the Right of Civilly Committed Mental Patients to Adequate Treatment, 86 HARv. L. REv. 1282, 1305 (1973). Although a friend or relative could initiate a judicial action, the cost of litigation and discovery can be prohibitive, especially in a suit attacking multifaceted institutional operations. See Alexander v. Hall, 64 F.R.D. 152, 154, 158 (D.S.C. 1974) (United States allowed to intervene in mental health right-totreatment case when plaintiffs would be financially unable to proceed with discovery).

To prevent constitutional rights from going unasserted, the House of Representatives has passed a bill, H.R. 10, 96th Cong., 1st Sess. (1979), that would provide the Justice Department with statutory authority to sue on behalf of a limited class of institu- 
the government's power to bring suit also could impair the executive's ability to seek expeditious relief in a national emergency. ${ }^{5}$

Two main arguments have been lodged against nonstatutory government standing. Some courts have held the United States unsuccessful in meeting the plaintiff's standing requirement of suffering injuryin-fact. ${ }^{6}$ Others have ruled that the separation-of-powers doctrine bars the executive from bringing suits not mandated by Congress. ${ }^{7}$

After exploring the ambiguities and difficulties of the current law of nonstatutory standing, this Note develops a theory of the public interest to guide determinations about the propriety of nonstatutory actions. The theory provides a framework within which the executive can warrant satisfaction of the injury-in-fact requirement in a limited range of cases. In response to the separation-of-powers objection against nonstatutory standing, the Note then examines the distinctive competences of Congress and the executive to determine in which cases it would be appropriate to permit the executive to pursue a judicial remedy despite congressional failure to authorize actions of the relevant kind. The Note concludes that the executive possesses independent authority to bring suit in two important categories of cases: claims to defend national security interests and actions to protect the constitutional rights of citizens.

tionalized persons. See 125 CoNG. REc. H3634-52 (daily ed. May 23, 1979) (recording debate and passage). Prospects for Senate action are uncertain. Although the House approved a similar bill, H.R. 9400, 95th Cong., 2d Sess. (1978), during the last session, see 124 CoNc. REC. H7489-90 (daily ed. July 28, 1978), the Senate failed to bring the measure to a vote. Even if passed, however, H.R. 10 would not authorize government suits to remedy violations of individual rights occurring outside of jails and mental institutions, such as the alleged violations that prompted government action in United States v. Philadelphia, C.A. No. 79-2937 (E.D. Pa., dismissed in part for lack of standing Oct. 30, 1979), New York Times, Oct. 31, 1979, at Al, col. 6, a suit to enjoin constitutional rights violations by the Philadelphia Police Department, and United States v. Brand Jewelers, Inc., 318 F. Supp. 1293 (S.D.N.Y. 1970), an action to enjoin widespread deprivations of the due process and Fourteenth Amendment rights of culturally deprived ghetto dwellers.

5. Cf. New York Times Co. v. United States, 403 U.S. 713, 732 (1971) (White, J., concurring) (citing government allegation of possible "grave and irreparable injury" to national security in nonstatutory suit to enjoin publication of Pentagon Papers); In re Debs, 158 U.S. 564, 592 (1895) (citing "general confusion" resulting from disrup. tion of commerce by Pullman strike).

6. See, e.g., United States v. Mattson, 600 F.2d 1295, 1300 (9th Cir. 1979); United States v. Biloxi Mun. School Dist., 219 F. Supp. 691, 694 (S.D. Miss. 1963), aff'd on other grounds, 326 F.2d 237 (5th Cir.), cert. denied, 379 U.S. 929 (1964). For a discussion of the law of standing, a doctrine concerned with the propriety of allowing a party to bring suit, see pp. 124-25 infra.

7. See, e.g., United States v. Solomon, 563 F.2d 1121, 1128.29 (4th Cir. 1977); United States v. Madison County Bd. of Educ., 219 F. Supp. 60, 61 (N.D. Ala. 1963), aff'd on other grounds, 326 F.2d 237 (5th Cir.), cert. denied, 379 U.S. 929 (1964). 


\section{Evolution of the Law: Drift to Confusion}

Prior to the past two decades, the law of nonstatutory standing underwent a slow but sustained expansion. Recent courts have identified difficulties in the established doctrine, and sometimes refused to apply it. Yet these courts have failed to formulate a satisfactory substitute.

\section{A. Genesis of Nonstatutory Standing}

Nonstatutory suits by the United States first appeared before the courts early in the nation's history. ${ }^{8}$ Lacking a guiding body of statutes, the judiciary faced the task of defining the rights of the United States, as a sovereign and representative entity, in a system of law that made few explicit provisions for government interests and actions. ${ }^{9}$ In this context, the early decisions recognized no essential difference between the United States and other parties plaintiff. The government was entitled to claim standing ${ }^{10}$ and to imply rights of action ${ }^{11}$ on the same terms as other legal persons.

8. See, e.g., Cotton v. United States, 52 U.S. (11 How.) 229, 231 (1850) (implying right of action for trespass quare clausum fregit without special statutory authorization); Dugan v. United States, 16 U.S. (3 Wheat.) 172, 181 (1818) (implying right to sue on contract). See generally P. Bator, P. Mishinin, D. Shapiro, \& H. Wechsler, Hart \& Wechsler's The Federal Courts and the Federal System 1293-1309 (2d ed. 1973).

9. Despite the acknowledged practical necessity for the government to be able to do so, early statutes did not authorize the United States to sue in tort or on a contract. See, e.g., Jessup v. United States, 106 U.S. 147, 152 (1882) (permitting suit on contract and noting absurdity of upholding validity of bond on which obligee could not sue); Cotton v. United States, 52 U.S. (11 How.) 229, 291 (1850) (implying right of action for trespass).

10. Standing doctrine implicates a varicty of barriers erected to test the propriety of allowing a plaintiff to bring suit. See pp. 124-25 infra. Chief among these barriers is the demand that a plaintiff, including the United States, allege that it has suffered injury-in-fact. See, e.g., United States v. San Jacinto Tin Co., 125 U.S. 273, 285 (1888) (government, like private individual, must show "such an interest in the relief sought as entitles it to move in the matter"); United States v. Mattson, 600 F.2d 1295, 1300 (9th Cir. 1979) (standing requirement that plaintiff be among injured not limited to private individuals and organizations but extends to government).

11. The implication of a right of action has been defined as "the extension of a civil remedy to one injured by another's breach of a statute or regulation not providing for such relief." Note, Implying Civil Remedies From Federal Regulatory Statutes, 77 Harv. L. Rev. 285, 285 (1963). In Cort v. Ash, 422 U.S. 66, 78 (1975), the Supreme Court enunciated four relevant factors to guide decisions about whether an implied right exists: (1) whether the plaintiff belongs to the class for whose special benefit the statute was enacted; (2) whether there was any indication of legislative intent to create such a remedy or to deny one; (3) whether a grant of relief would be consistent with the underlying purposes of the legislative scheme; and (4) whether the cause of action is traditionally relegated to state law. Although the Court has not expressly formulated alternative standards, the same criteria cannot be applied in implying rights of action from the Constitution, because congressional intent plays no significant role. See Davis 
The parallelism between government and private plaintiffs broke down, however, in a series of cases brought by the United States in its representative capacity to discharge duties owed the general public. ${ }^{12}$ Although at least two earlier cases foreshadowed that the government's right to bring actions might be broader than that of private parties, ${ }^{13}$ the Supreme Court's 1895 decision in In re Debs ${ }^{14}$ is generally considered to provide the modern foundation for nonstatutory governmental suits to protect the public interest. ${ }^{15}$ Debs arose from the 1894 Pullman strike, which paralyzed rail traffic and threatened mob violence. ${ }^{16}$ Alleging that strike activities had caused dan-

v. Passman, 99 S. Ct. 2264, 2277-78 (1979) (damages relief available to victims of constitutional rights violations in absence of explicit congressional declaration to withhold that remedy).

12. See In re Debs, 158 U.S. 564,586 (1895) (suit to remove obstruction of commerce); United States v. American Bell Tel. Co., 128 U.S. 315, 367 (1888) (suit to annul patent obtained by fraud).

13. In United States v. American Bell Tel. Co., 128 U.S. 315 (1888), the Court held that the government's "obligation to protect the public" could form the "essence of the right of the United States" to sue, even in the absence of either statutory authorization or pecuniary injury to the government. $I d$. at 367 . The Court in Bell Telephone found support for its holding in United States v. San Jacinto Tin Co., 125 U.S. 273 (1888), which had upheld the government's right to sue for cancellation of a deed allegedly procured by fraud on the General Land Office. San Jacinto presented a standing question because the Land Office, as a patenting agent, sought to reclaim the land only in order to transfer it at a later date to some third party. $I d$. at 286. The government alleged no pecuniary loss as a result of the fraud, and the defendant claimed that the United States functioned only as a placeholder for the real party in interest, a specific private claimant to the land in issue. In upholding government standing, the San Jacinto Court seemed to place weight on the government's expressed property interest in reclaiming the land it had surrendered. See id. at 286-87. But, as asserted in Bell Telephone, 128 U.S. at $366 \cdot 67$, the San Jacinto decision also contained language suggesting that the government might claim standing to sue on the basis of the "obligation on the part of the United States to the public." 125 U.S. at 285-86.

14. 158 U.S. 564 (1895).

15. Debs's position as the leading case authorizing nonstatutory suits by the executive has been recognized both by courts, see United States v. Solomon, 563 F.2d 1121, 1126-29 (4th Cir. 1977); United States v. Brand Jewelers, Inc., 318 F. Supp. 1293, 1295 (S.D.N.Y. 1970), and by commentators, see, e.g., Note, Implied Executive Authority to Bring Suit to Enforce the Rights of Institutionalized Citizens, 26 CaTH. U.L. REv. 794, 797-803 (1977); Note, supra note 2, at 1568.

Debs differs from the earlier cases principally because the government's right of action was implied from the Constitution rather than from a statutory scheme. In United States v. San Jacinto Tin Co., 125 U.S. 273 (1888), the award of patents to land had been entrusted by Congress to the Interior Department. Id. at 301.02 (Field, J., concurring). There was also extensive congressional regulation of the award of patents of invention, as noted by the Court in United States v. American Bell Tel. Co., 128 U.S. 315, 370-72 (1888). Because Congress had not authorized a cause of action for the particular injury alleged, Debs allowed the executive to claim standing on the basis of injuries to the public not statutorily identified by Congress as injuries to the United States.

16. See generally A. Lindsey, The Pullasan Strike (1942). 
gerous and unlawful interference with interstate commerce, the Attorney General obtained a federal injunction against coordinating efforts by Debs and other union leaders. ${ }^{17}$

The government's property interest in the mails provided grounds for standing, ${ }^{18}$ and the Sherman Act offered a statutory basis for the government's right to relief. ${ }^{19}$ But the Supreme Court unanimously chose to go beyond these rationales. The Court held that the basis for the government's right of action lay in the Constitution itself.20 Obligations arising from the relationship between the government and its citizens provided the requisite interest for standing. ${ }^{21}$

By allowing the United States to satisfy the standing requirement by citing an injury to the public or the public interest, rather than to itself as a legal entity, the Supreme Court recognized that the United States was different from other legal persons. Its relationship to its citizens created what the Court had termed an "obligation to protect the public" that could form "[t]he essence of the right of the United States" to standing in a federal court. ${ }^{22}$

\section{B. Debs as Precedent: Ambiguity and Extension}

The Supreme Court's unanimous pronouncement in Debs clearly rested on some concept of executive authority to go to court to seek vindication of certain constitutional objectives. Congressional authorization was not required. ${ }^{23}$ Yet, as subsequent litigation has dem-

17. 158 U.S. at $565-66,570$.

18. See $i d$. at 583 .

19. The circuit court had in fact rested its jurisdiction on the Sherman Act. See

United States v. Debs, 64 F. 724, 745-55 (7th Cir. 1894), aff'd, 158 U.S. 564 (1895).

20. 158 U.S. at 586 .

21. The Court stated:

[W] henever the wrongs complained of are such as affect the public at large, and are in respect of matters which by the Constitution are entrusted to the care of the Nation, and concerning which the Nation owes the duty to all the citizens of securing to them their common rights, then the mere fact the government has no pecuniary interest in the controversy is not sufficient to exclude it from the courts, or prevent it from taking measures therein to fully discharge those constitutional duties.

Id.

22. United States v. American Bell Tel. Co., 128 U.S. 315, 36 ' (1888).

23. One weakness of the Debs opinion is that it never confronts the separation-ofpowers issues raised by nonstatutory suits. Justice Brewer's opinion refers recurrently to "the government." See, e.g., id. at 583, 586. As a consequence, Debs fails to consider the relevance of possible disagreement between the branches, as, for cxample, when Congress has rejected legislation creating the right of action that the executive later seeks to imply. Cf. Youngstown Sheet \& Tube Co. v. Sawyer, 343 U.S. 579, 637 (1952) (Jackson, J., concurring) (President's power at its "lowest ebb" when he takes measures incompatible with "expressed or implied will of Congress"). For discussion of the separation-of-powers issues raised by nonstatutory executive standing, see pp. 132-43 infra. 
onstrated, the Debs opinion opened more questions than it answered.24 Since 1895, courts have invoked Debs to support government suits to protect public property ${ }^{25}$ and to prevent obstructions of commerce. ${ }^{26}$ The national executive has claimed nonstatutory standing under $D e b s$ to litigate actions pursuant to its national security powers. ${ }^{27}$ During the 1960's, the Justice Department cited Debs in numerous suits under the commerce clause and the war powers clause to protect black citizens from racial discrimination. ${ }^{28}$ Taking a broad view of the Debs concept of the public interest, the national executive, within the past decade, has brought actions to protect the constitutional rights of ghetto dwellers ${ }^{29}$ and of patients in state hospitals. ${ }^{30}$

By expanding the range of public interest actions to include suits to protect individual rights, the post-1960 civil rights cases have raised important questions about the meaning of Debs. Debs upheld the right of the executive to invoke the judicial process to promote certain constitutional objectives and to protect the public interest, particularly when no citizen would have standing to do so. ${ }^{31} \mathrm{Yet}$, as

24. Compare United States v. Brand Jewelers, Inc., 318 F. Supp. 1293, 1299 (S.D.N.Y. 1970) (gist of Debs was impact 'sufficient in its dimensions to be thought 'public' rather than 'private' ") with United States v. Solomon, 563 F.2d 1121, 1129 (4th Cir. 1977) (Debs does not authorize suits where Congress has withheld authorization and there is "no factor of interstate commerce" or emergency). One commentator has argued that Debs is susceptible of at least five separate interpretations. See Note, supra note 2, at 1569-70.

25. Robbins v. United States, 284 F. 39, 46 (8th Cir. 1922) (prohibiting unauthorized carriage of passengers in national park).

26. Sanitary Dist. v. United States, 266 U.S. 405, 425-26 (1925) (suit to enjoin diversions of water from Lake Michigan); Florida E. Coast Ry. Co. v. United States, 348 F.2d 682, 685 (5th Cir. 1965) (suit to enjoin improper changes in collective bargaining agreements that would create threat to flow of commerce).

27. New York Times Co. v. United States, 403 U.S. 713 (1971) (suit to enjoin publication of Pentagon Papers); United States v. Arlington County, 326 F.2d 929, 932-33 (4th Cir. 1964) (government interest in implementing policies and programs involving national defense sufficient to vest nonstatutory authority to sue to protect servicemen from taxes barred by federal law).

28. See, e.g., United States v. Brittain, 319 F. Supp. 1058 (N.D. Ala. 1970) (action under war powers to enjoin enforcement of antimiscegenation statute invoked against military personnel); United States v. City of Jackson, 318 F.2d 1 (5th Cir. 1963) (action to free commerce from burden of racial segregation). See generally Dixon, Civil Rights in Transportation and the ICC, 31 GEo. WASH. L. REv. 198 (1962).

29. United States v. Brand Jewelers, Inc., 318 F. Supp. 1293 (S.D.N.Y. 1970).

30. United States v. Solomon, 419 F. Supp. 358 (D. Md. 1976), aff'd, 563 F.2d 1121 (4th Cir. 1977); United States v. Mattson, C.A. No. 74-138-BU (D. Mont. Sept. 28, 1976), aff'd, 600 F.2d 1295 (9th Cir. 1979).

31. The government argued Debs on a nuisance theory, and the Supreme Court analyzed the case in traditional nuisance terms. See 158 U.S. at 586-93. That mode of analysis is significant. In traditional cases of public nuisance, defined as an act or omission that "obstructs or causes inconvenience or damage to the public in the exercise of rights common to all," W. Prosser, THE LAw of ToRTs 583 (4th ed. 1971) (footnotes omitted), no one citizen may suffer an injury distinguishable from those suffered by all others. Yet, where the injury to members of the public is "undifferentiated," the common law standing doctrine assumed in Debs held that "[r]edress of the wrong to 
courts and critics have noted, Debs provided no adequate criteria for determining when injuries suffered by private individuals constitute injury to the public interest and hence justify executive claims of government standing. ${ }^{32}$

\section{Objections to the Debs Theory}

Debs's ambiguity as to the limits on nonstatutory standing has had two effects. On the one hand, the government has expanded the class of actions in which it asserts standing. ${ }^{33}$ On the other, lower courts increasingly have rejected government claims to nonstatutory standing. ${ }^{34}$ Recent decisions have held that acceptance of the expansive Debs theory would support interference by the federal executive in matters reserved to the states, to private citizens, or to Congress. ${ }^{35}$

Courts have developed two lines of argument against executive claims of nonstatutory government standing. The first and more basic objection denies that injuries to citizen interests qualify as injuries to the government sufficient to fulfill the injury-in-fact requirement of federal standing doctrine. ${ }^{36}$ This issue, which might be

the community must be left to its appointed representatives." W. Prosser, supra, at 586. 87; see United States v. Richardson, 418 U.S. 166, 177 (1974) (denying taxpayer standing to challenge expenditure-reporting practices of Central Intelligence Agency because alleged injury was "undifferentiated" and common to all members of public). According to Prosser, supra, at 587, "[t]he best reason that has been given for the rule [requiring particular damage for nuisance standing] is that it relieves the defendant of the multiplicity of actions which might follow if everyone were free to sue for the common harm." (footnote omitted.) Yet the rule presupposes authority in the government to sue to redress harms to the public arising from the nuisance. Significantly, the Court in Debs spoke of the government's responsibility to protect its citizens not as a right but as a "duty." 158 U.S. at 586 .

32. See United States v. Solomon, 563 F.2d 1121, 1127 (4th Cir. 1977); Note, supra note 2 , at $1569-7 \mathrm{I}$.

33. See, e.g., United States v. Solomon, 563 F.2d 1121 (4th Cir. 1977) (denying government standing to protect rights of patients in Maryland state hospital for mentally retarded); United States v. Brand Jewelers, Inc., 318 F. Supp. 1293 (S.D.N.Y. 1970) (upholding standing to seek to enjoin operation by which defendant obtained default judgments from ghetto dwellers in violation of due process of law).

34. See, e.g., United States v. Solomon, 563 F.2d 1121 (4th Cir. 1977) (dismissing suit to protect rights of mental patients); United States v. Madison County Bd. of Educ., 219 F. Supp. 60, 61 (N.D. Ala. 1963), aff'd on other grounds, 326 F.2d 237 (5th Cir.), cert. denied, 379 U.S. 929 (1964) (dismissing suit to enjoin segregation in schools attended by children of United States military personnel).

35. See, e.g., United States v. Mississippi, 229 F. Supp. 925, 945 (S.D. Miss. 1964), rev'd, 380 U.S. 128 (1965) (three-judge court) (characterizing suit as "an attack against a state aimed at destroying its action in a field committed exclusively to it by the Constitution"); United States v. Madison County Bd. of Educ., 219 F. Supp. 60, 61 (N.D. Ala. 1963), aff'd on other grounds, 326 F.2d 237 (5th Cir.), cert. denied, 379 U.S. 929 (1964) (terming suit "an attempt by the executive arm of the Government . . . to bypass the legislative arm").

36. See, e.g., United States v. Mattson, 600 F.2d 1295, 1300 (9th Cir. 1979); United States v. County School Bd. of Prince George County, 221 F. Supp. 93, 103-05 (E.D. Va. 1963). 
categorized as one of pure or traditional standing, arises from the Article III limitation of federal jurisdiction to "cases" and "controversies." 37 In order to present a justiciable case, a plaintiff must establish a "personal stake" in the outcome of the litigation. ${ }^{38}$ The Supreme Court has held that a plaintiff can satisfy this demand only by alleging injury to some real or legal interest of his own. ${ }^{39}$ When the injury requirement is elevated to the constitutional level, the crucial question for government standing is how the United States, as a sovereign and representative entity, suffers injury-in-fact. ${ }^{40}$

In addition to this traditional standing argument, courts have asserted a second ground for denial of jurisdiction, also based on the doctrine of standing. In nonstatutory suits by the United States, courts have sometimes held that the government cannot be a legally appropriate plaintiff because Congress has not authorized executive actions of the kind attempted. ${ }^{41}$ To permit unauthorized suits, it is argued, would enable the executive "to use the judicial arm to bypass the legislative arm" 42 and "threaten the delicate balance of power which the Constitution conceives among the various branches." 43 This argument also buttresses the injury-in-fact objection, because the separation-of-powers doctrine has been held to signify that Congress alone can identify the legally assertable interests of the United States. ${ }^{44}$

\section{Tensions and Confusion}

Recent lower court decisions have of course not purported to overrule Debs. They have endeavored instead to construe it as creating

37. U.S. Const. art. IIT, \$ 2; see Warth v. Seldin, 422 U.S. 490, 499-501 (1975) (no case or controversy presented unless plaintiff alleges personal injury); $c f$. Baker v. Carr, 369 U.S. 186, 204 (1962) (gist of standing inquiry is to determine whether parties have alleged such "personal stake" in outcome as to assure "concrete adverseness" on which Court relies for "illumination of difficult constitutional questions").

38. Duke Power Co. v. Carolina Environmental Study Group, Inc., 438 U.S. 59, 72 (1978); Warth v. Seldin, 422 U.S. 490, 499 (1975); see Linda R.S. v. Richard D., 410 U.S. 614, 617 (1973) (plaintiff must allege "threatened or actual injury").

39. Duke Power Co. v. Carolina Environmental Study Group, Inc., 438 U.S. 59, 72 (1978); Warth v. Seldin, 422 U.S. 490,499 (1975).

40. But see Berger, Standing to Sue in Public Actions: Is it a Constitutional Requirement? 78 YALE L.J. 816 (1969) (arguing allegation of injury to the plaintiff is not a constitutional prerequisite to federal jurisdiction under article III).

41. See, e.g., United States v. Solomon, 563 F.2d 1121, 1129 (4th Cir. 1977); United States v. Madison County Bd. of Educ., 219 F. Supp. 60, 61 (N.D. Ala. 1963), aff'd on other grounds, 326 F.2d 237 (5th Cir.), cert. denied, 379 U.S. 929 (1964).

42. United States v. Madison County Bd. of Educ., 219 F. Supp. 60, 61 (1963), aff'd on other grounds, 326 F.2d 237 (5th Cir.), cert. denied, 379 U.S. 929 (1964).

43. United States v. Solomon, 419 F. Supp. 358, 361 (D. Md. 1976), aff'd, 563 F.2d 1121 (4th Cir. 1977).

44. See United States v. Solomon, 563 F.2d 1121, 1125-26 (4th Cir. 1977) (acknowledging that United States has interest in state's treatment of retarded citizens but holding executive lacks authority to sue to protect that interest). 
only a narrow exception to a general principle forbidding nonstatutory suits by the United States. ${ }^{45}$ In United States $v$. Solomon, ${ }^{46}$ a leading case denying government standing to protect constitutional rights of institutionalized persons, the Fourth Circuit implied that the Debs holding should be construed as limited by some special factor or set of factors. ${ }^{47}$ At least one commentator has urged restricting the executive's authority to bring nonstatutory suits only to instances exhibiting the Debs factor of national emergency. ${ }^{48}$ But neither Solomon nor any other case denying government standing to sue has propounded a coherent doctrine that would support both its own decision and principled exceptions to the proposed general rule against nonstatutory suits.

The Solomon decision, for example, did not challenge the public interest rationale as a justification for nonstatutory suits, at least in a narrow set of contexts including emergencies. ${ }^{49}$ Having recognized a limited executive right to nonstatutory standing, however, the court failed to develop the necessary logical relationship between the concept of the public interest and its own constitutional objections to nonstatutory standing in other situations. ${ }^{50}$ The court left unclear how the injury-in-fact and separation-of-powers arguments apply to some but not to other cases.

The uncertainty and confusion in the law of standing, which originate in Debs and continue in cases delimiting it, derive from two main failures of analysis. Even when adjudicating government standing to protect the public interest, no court has looked closely at the operative concept in order to determine what the public interest is and how it suffers injury. Similarly, the separation-of-powers objection either has been ignored by courts upholding standing or, in the case of courts denying standing, has been assumed without sufficient argument to be compelling. To be coherent and viable, a theory of

45. See, e.g., United States v. Solomon, 419 F. Supp. 358, 366, 368 (D. Md. 1976), aff'd, 563 F.2d 1121 (4th Cir. 1977) (suggesting that crucial variable in Debs was "emergency," as implicitly recognized by subsequent cases); United States v. Mattson, 600 F.2d 1295, 1298-99 (9th Gir. 1979) (nonstatutory suits permitted only to protect government property interests or prevent interference with national security or burdens on commerce).

46. 563 F.2d 1121 (4th Cir. 1977).

47. Among the "particular elements of the facts" on which Debs could be treated as "depending," the Fourth Circuit listed: a situation of national emergency, the presence of a statute on which the decision could be based, the element of nuisance, id. at 1127, and the factor of interstate commerce, $i d$. at 1129 .

48. See Note, supra note 2 , at 1575,1581 .

49. See 563 F.2d at $1127,1129$.

50. See id. (objecting to nonstatutory standing). 
nonstatutory, public interest litigation would need to confront both the conceptual and separation-of-porwers issues and to resolve them.

\section{A Theory of Public Interest Standing}

When courts have permitted nonstatutory standing by the United States, they have invoked the concept of the public interest to satisfy two demands. First, the concept must link citizen interests to government interests in such a way that the United States satisfies the injury requirement for plaintiff's standing. Second, it must define and limit the class of nonstatutory suits that the executive can bring. A conception of the public interest compatible with American legal culture can be constructed from a variant of the theory propounded by utilitarian philosopher Jeremy Bentham. ${ }^{51}$

\section{A. An Aggregationist Approach}

The master task for a theory of the public interest is to define the relationship between the public interest ${ }^{52}$ and the private interests

51. See J. Bentham, An Introduction to the Principles of Morals and Legislation (Hafner ed. 1970).

52. Political theorists have propounded three main types of conception of "the public interest": preponderance, common interest, and unitary theories. V. HeLd, THE PUBLIC Intcrist and Individual Interests $42-46$ (1970). Preponderance theories, of which Bentham's aggregationist conception is prototypical, hold that the public interest consists in the preponderance or sum of individual interests. This Note utilizes an aggregationist theory because neither the unitary nor the common interests conceptions provide an analysis of the public interest that is analytically useful within the context of American legal culture.

Unitary theories hold that certain policies are objectively best for the state, which has an interest transcending that of its citizens. See, e.g., G. HEGEL, THE PHILOsOpHY of RIGHT (T. Knox ed. 1942); Plato, The Rapublic (F. Cornford ed. 1945). Because of the superior importance of the state, to which the citizen stands in an organic relation, no one could rationally wish to advance his private interests against those of the whole. Unitary theories are fundamentally incompatible with the assumptions of a pluralist society that strives to protect individual rights even against state interests.

The third leading conception identifies the public interest with those interests held in common by all citizens of a polity. See, e.g., J.J. Rousseav, The Social Contract and Discourses (Everyman's ed. 1973); Barry, The Public Interest, in Political Philosophy $112,119-23$ (A. Quinton ed. 1967). The fundamental problem with common interest theories is that they fail to provide a means of determining the public interest except in a narrow range of cases. Rousseau, for example, thought the common interests underlying his theory of "the general will" unidentifiable, if not nonexistent, in advanced, pluralistic societics. See J.J. Rousseav, supra, at 185. Brian Barry, Rousseau's most prominent modern disciple, has attempted to meet the challenge of pluralism by $a b$ stracting a person's "particular" interests, which he holds in one or another capacity (e.g., parent, lawyer, homeowner, or taxpayer), from his "net" interest, which reflects, on balance, how well off he is. Even in a complex society, Barry argues, there is one role common to all citizens: that of a member of the public. Interests held by all citizens in this capacity are "public interests." See Barry, supra, at 123-24. One difficulty 
of individual citizens. ${ }^{53}$ Bentham related private interests to the public interest through a process of aggregation. Rejecting metaphysical constructs, he argued that the public consists of nothing but individual citizens, whose interests lie in achieving pleasure and avoiding pain..$^{54}$ From this premise Bentham reasoned that the public interest must consist of the sum of individual interests. 55 Bentham equated pursuing the public interest with seeking to maximize the sum of all pleasures and minimize the sum of all pains in society as a whole. ${ }^{50}$

As a goal for public policy, Bentham's aggregationist theory provides a neutral standard under which every person is to count for one and none for more than one. The theory also offers a plausible model of the relationship between citizens and their governments. Because the United States is a collective entity, comprised of individual citizens with individual interests, the interests of citizens are in one sense the interests of the United States. The aggregationist conception of the public interest thus suggests how, and why, the United States could satisfy the injury-in-fact requirement for standing when it sues to protect citizen interests. In theory at least, Bentham's model also would place an enforceable limit on the nonstatutory suits that could be justified by appeal to the public interest. The government could bring only such actions as would produce a net increase in public satisfaction. If the result would be merely a reallocation of benefits, executive action would not be appropriate.

Despite its virtues, the specific theory propounded by Bentham must be amended before it can provide an adequate standard for legal analysis. There are two main difficulties. First, to calculate the public interest, the pains and pleasures of one person must be compared with those of others, so that the optimizing solution can be determined. ${ }^{57}$ Yet there is no objective, verifiable way to accomplish the necessary weighing. Precise interpersonal comparisons of utility are blocked by epistemological constraints that no theorist has yet surmounted. ${ }^{58}$

with this conception is that it may completely ignore many of a person's most important interests. Further, Barry's theory will frequently result in a conflict of public interests. For example, the public interest in industrial development might conflict with the public interest in clean air. When conflicts occur, Barry propounds no mechanism for choice. His theory would therefore establish no plausible operational limits on the scope of government standing, at least in cases where common interests came in conflict.

53. See V. HELD, supra note 52 , at $18-48$.

54. See J. BenthaM, supra note 51 , at 3 .

55. Id.

56. Id. at 38-41.

57. See id. at $30-31$.

58. See, e.g., K. Arrow, Social Choice and Individual Values 10-11 (2d ed. 1964) ("It seems to make no sense to add the utility of one individual, a psychic magnitude in his 
A second, equally severe objection goes to the moral foundations of Bentham's theory. The "public interest" is a normative as well as a descriptive concept. It does not merely denote some relationship between individual and government interests; it functions to justify government actions. ${ }^{50}$ Bentham, who postulated pleasure and pain as the standards of right and wrong, derived moral conclusions from the result of aggregation. But interests must be asserted within a system, ${ }^{60}$ and the system created by the American Constitution privileges certain rights against utilitarian arguments. It frequently aims to protect individual interests against the claims of popular utility. ${ }^{61}$ Bentham's theory thus fails to explain how the concept of the public interest functions as a justification for action in a society recognizing the primacy of individual rights.

\section{B. The Theory Reformulated}

The normative difficulty with Bentham's view of the public interest derives from his conception of "interests." Bentham equated interests with pleasure-maximization, an interpretation that fails to capture the distinctive feature of "legal interests." Although legal interests may exist to promote want-satisfaction, ${ }^{62}$ legal interests differ from mere wants and pleasures because of their location in a nonutilitarian scheme of justifications and protections. For a Benthamite theory to be applicable within the American legal culture, citizen pleasures could be allowed to count in an aggregative public interest only to the extent that they did not result from the violation of cer-

mind, with the utility of another individual."); L. RoBBINs, AN ESSAY oN THE SIGNIFICANCE of ECoNomic ScIENCE 140 (2d ed. 1952) (psychic satisfactions of different persons not commensurable). Modern economists have sometimes tried to surmount the epistemological barrier by constructing operational definitions that equate utility with observable behaviors. See, e.g., J. Von Neumann \& O. Morgenstern, Theory of Games and Economic Behavior 17-28 (2d ed. 1953). But operational tests give no indication of the relative strengths of people's feelings; they only compare relative proclivities to behave in certain ways. See generally Ellsburg, Classic and Current Notions of Measurable Utility, 64 Econ. J. 528 (1954).

59. See R. Flathiam, The Public Interest 38 (1966).

60. Cf. Fried, Two Concepts of Interests: Some Reflections on the Supreme Court's Balancing Test, 76 HARv. L. REv. 755, 756.57 (1963) (distinguishing between "wants, that is, bare demands for satisfaction . .. and interests . . . which represent appeals to some existing or proposed scheme of justification").

61. See Bivens v. Six Unknown Agents, 403 U.S. 388, 407 (1971) (Harlan, J., concurring) (" $[\mathrm{T}]$ he Bill of Rights is particularly intended to vindicate the interests of the individual in the face of the popular will ... .); Lawton v. Steele, 152 U.S. 133, 137 (1894) ("The legislature may not, under the guise of protecting the public interests, arbitrarily interfere with private business. ..."); R. Dworkin, TAKING Rights SERIOUSLY $132-33$ (1977).

62. See R. Posner, Economic Analysis of LAw 10-104 (1972) (arguing legal rules developed to serve utility-maximizing goal of efficient resource allocation). 
tain specially protected rights of others. ${ }^{63}$ Those specially protected rights include rights safeguarded by the Constitution of the United States and by the prohibitions of the criminal law. Furthermore, because the American legal system values some rights more highly than others, ${ }^{64}$ an adequate theory of the public interest would have to assign adjusted weights to the satisfactions accompanying the exercise of rights of varying importances.

The most highly valued rights under an adjusted Benthamite system would be constitutional rights. Yet constitutional rights are of two kinds-"abstract" and "concrete"-that need to be distinguished.

Courts sometimes have suggested that even constitutional rights can be overridden, in particular cases, following an ad hoc balancing test. $^{65}$ This formulation, which makes it appear that no right could ever be assigned a fixed weight or value, collapses the distinction between abstract and concrete rights. ${ }^{66}$ Abstract rights express legal principles of high generality, such as the right to publish and the right to privacy. When applied to particular cases, abstract rights frequently conflict, and therefore must be balanced by courts and legislatures. For example, in adjudicating a libel case, a court may have to weigh one citizen's abstract right to privacy against another

63. There are some circumstances in which the American legal system arguably does take account of the satisfactions derived from rights violations. In a torts case, for example, a court might award money damages for the harm caused by an industry that pollutes the air, yet, due to the importance of the industry to a local economy, refuse to enjoin the industry from operating. See Madison v. Ducktown Sulphur, Copper \& Iron Co., 113 Tenn. 331, 83 S.W. 658 (1904); Developments in the Law-Injunctions, 78 HARv. L. Rev. 994, 1006 (1965). Yet the protection of other, constitutionally more important rights, is not subject to the same kind of calculus. See, e.g., Cooper v. Aaron, 358 U.S. 1, 16-17 (1958) (constitutional right to attend desegregated schools may not be sacrificed to preserve law and order); Buchanan v. Warley, 245 U.S. 60, 81 (1917) (protection of constitutional rights takes precedence over maintenance of public peace).

64. Compare Dunn v. Blumstein, 405 U.S. $330,342-43$ (1972) (statute penalizing exercise of constitutional rights unconstitutional unless necessary to promote compelling government interest) with Massachusetts Bd. of Retirement v. Murgia, 427 U.S. 307, 312 (1976) (legislative classification impinging on nonfundamental right constitutional so long as supported by rational basis). The distinction between fundamental and nonfundamental rights is frequently drawn in cases arising under the equal protection clause of the Fourteenth Amendment. See Gunther, The Supreme Court, 1971 Term-Foreword: In Search of Evolving Doctrine on a Changing Court: A Model for a Newer Equal Protection, 86 HARv. L. Rev. 1, 8-10 (1972).

65. See, e.g., Barker v. Wingo, 407 U.S. 514, $5 \& 0$ (1972) ("[b]alancing test necessarily compels courts to approach speedy trial cases on an ad hoc basis"); Barenblatt v. United States, 360 U.S. 109, 126 (1959) ("Where First Amendment rights are asserted to bar governmental interrogation resolution of the issue always involves a balancing by the courts of the competing private and public interests. ....")

66. Cf. R. Dworkin, supra note 61, at 93-94 (developing similar distinction between abstract rights as "general political aims" and concrete rights as "more precisely defined" aims). 
citizen's abstract right to publish. ${ }^{67}$ Until it has been balanced against others, any one abstract right does not determine how a citizen may legally behave in a certain context, or who should prevail in a lawsuit. But when courts adjudicate cases involving conflicts of abstract rights, they affirm the existence of concrete rights, such as an absolute right to publish whenever certain factors do and others do not obtain. These concrete rights represent the ultimate end-products of the balancing process. ${ }^{\circ 8}$ They could be assigned constant values and would, in turn, provide the basis for calculations of the public interest.

Benthamite theory, supplemented by the distinction between abstract and concrete rights, provides a framework that relates citizen interests to the public interest, as follows:

The public interest consists in the maximization of the sum of citizen satisfactions, subject to the following qualifications:

(I) Satisfactions arising from the violation of specially protected rights cannot be counted; and

(2) Satisfactions arising from the exercise of concrete rights must receive a weighting in the utility calculus commensurate with the value assigned to those rights by the constitutional scheme.

\section{Calculating the Public Interest}

Under a system of separated powers, formulation of a theory of the public interest does not establish which branch of government should determine when injury to that interest has occurred. In addition to the question of institutional competence, the issue arises whether an injured person is not the only appropriate advocate of his rights.

\section{A. Institutional Competence}

A theory of the public interest is necessarily abstract. Utilities can be estimated, and the estimates acted upon. But while theory can provide a framework for analysis, the impossibility of measuring utili-

67. See Rosenblatt v. Baer, 383 U.S. 75, 92 (1966) (Stewart, J., concurring).

68. Although courts recognize the existence of concrete rights when they adjudicate cases, concrete rights can exist, and therefore possess determinable weights, prior to judicial determination. The existence of a right may be so well established that no litigation arises. Moreover, even in controversial cases, court decisions may represent the enunciation of previously existing rights and duties, rather than the judicial creation of rights and duties after the fact. Cf. R. Dworkin, supra note 61, at 81-130 (arguing law provides one right answer to all legal questions, so judges need never create new rights or duties to decide cases). 
ties against a verifiable public standard generally will make it impossible to prove that an analysis is correct, and that a government action, such as a lawsuit, either would or would not advance the sum of citizen interests. In determining whether a given action is appropriate, it therefore becomes necessary to assess which branch of government, as a matter of constitutional theory and practical capability, is best able to compute costs and benefits.

\section{Statutory Interests: Congress}

This focus on institutional competences creates a barrier to nonstatutory government standing in a large class of cases. Under the American political system, in which each of the three branches of government is presumed to have special competence within its respective sphere, the task of estimating, weighing, and balancing citizen satisfactions ordinarily resides in Congress. When rights are created by statute, it is presumed that Congress has constructed the package of rights and grants of standing to enforce those rights that best reflects its balancing of all pertinent factors, ${ }^{69}$ including enforcement costs. ${ }^{70}$

Thus, in claims of standing to enforce statutory rights, executive invocation of the public interest should possess little persuasive force. Although executive enforcement of rights presumably would advance some citizen interests, others might be damaged, with a net decline in the sum of public satisfactions. Lacking epistemological competence to resolve any uncertainty, courts should regard the task of determining the public interest in vindicating statutory rights as constitutionally delegated to the legislative branch. Similarly, constitutional responsibility for assessing and protecting interests in commerce vests in Congress under Article $1 .^{71}$ For this reason, executive claims to nonstatutory standing under the commerce clause also merit little weight from courts.

69. Cf. Davis v. Passman, 99 S. Ct. 2264, $2274-75$ (1979) ("Statutory rights and obligations are established by Congress, and it is entirely appropriate for Congress, in creating these rights and obligations, to determine... who may enforce them and in what manner"); National R.R. Passenger Corp. v. National Ass'n of R.R. Passengers, 414 U.S. 453, 462-64 (1974) (private plaintiff has no implied right of action under statute authorizing Attorney General to represent public rights, because recognizing myriad plaintiffs would undercut congressional purpose of facilitating reduction of rail service).

70. See Scott, Standing in the Supreme Court-A Functional Analysis, 86 Harv. L. REv. 645, 670-83 (1973) (function of standing doctrine is to ration scarce judicial resources).

71. U.S. Consr. art. I, $\$ 8$, cl. 3 . 


\section{National Security: The Executive}

Claims of executive standing under the national security power take place in a context that calls for a different mode of analysis. In his capacity as "the sole organ of the nation in its external relations,"72 the President possesses both special responsibility and special competence to weigh the interests affected by threats to national security. ${ }^{73}$ The executive also has intelligence-gathering resources not available to any other branch. ${ }^{74}$ Thus, although any calculation of interests may be disputable, the President has a stronger claim than Congress or the courts to settle the threshold standing question of "actual or threatened injury" to United States interests in cases of danger to the national security.

\section{Individual Rights: The Constitutional Calculus}

Executive suits to enforce constitutional rights do not present the same issues of epistemological uncertainty and institutional competence as do actions under statutes, the commerce clause, and the national security power. The American legal system, which creates concrete constitutional rights that are privileged against all competing claims, establishes a structure in which it can be irrebuttably presumed that there is a public interest in safeguarding those rights. Courts are not permitted to weigh competing interests in deciding cases; ${ }^{75}$ Congress may not do so in enacting legislation. ${ }^{76}$ The struc-

72. United States v. Curtiss-Wright Export Corp., 299 U.S. 304, 319 (1936).

73. The President's national security powers derive from U.S. CoNST. art. II, § 2. For a historical discussion of the evolving understanding of the President's powers and duties in international affairs, see E. Corwin, The President, Office and Powers 1787-1957 at 170.226 (4th rev. ed. 1957).

74. Chicago \& S. Air Lines, Inc. v. Waterman S.S. Corp., 333 U.S. 103, 111 (1948) (Jackson, J.).

75. See, e.g., Cooper v. Aaron, 358 U.S. I, 16-17 (1958) (constitutional right to attend desegregated schools may not be sacrificed to preserve law and order); Buchanan $v$. Warlcy, 245 U.S. 60, 81 (1917) (protection of constitutional rights takes precedence over maintenance of public peace).

76. The Fourteenth Amendment provides that Congress "shall have power to enforce" its provisions by "appropriate legislation." U.S. Consr. amend. XIV, $\$ 5$. Yet this provision does not give Congress discretionary authority to narrow the scope of the amendment, or to determine that its enforcement should be limited. See Katzenbach v. Morgan, 384 U.S. 641, 651 n.10 (1966) (\$ 5 power limited to enforcing rather than diluting Amendment's guarantees). Nor does $\$ 5$ suggest that a congressional weighing of interests is needed to establish whether a traditional judicial remedy, such as injunctive relief, would serve the public interest. The Amendment is self-executing; persons whose rights are violated would have standing to sue for injunctive relief even in the absence of an implementing statute. See Karst, The Fifth Amendment's Guarantee of 
ture of the constitutional system thus warrants the conclusion that the enforcement of concrete constitutional rights is always in the public interest, provided only that the rights-holders want the rights enforced. ${ }^{77}$

Prior to a decision in court, it may, of course, be uncertain whether a violation of constitutional rights exists, and whether a consequent injury to the public interest has occurred. But the executive, far more than Congress, possesses the resources to ascertain the existence of injury in any particular case, and to assess whether the United States should claim standing to litigate a claim of rights abridgement. ${ }^{78}$

\section{B. The Jus Tertii Doctrine and Public Interest Suits}

Even within his sphere of presumptive calculative competence, the executive's capacity to claim public interest standing should remain subject to a qualification. The American legal system does not consider favorably the assertion by one party of rights held by another. When an aggrieved person does not choose to bring a lawsuit, the law ordinarily assumes that he has no rights to claim, or that the value to him of the abridged interest was not great. ${ }^{70} \mathrm{~A}$ Benthamite theory of the public interest also accepts these assumptions, which find expression in the established legal doctrine of jus tertii. ${ }^{80}$

Equal Protection, 55 N.C. L. REv. 541, $541-42$ (1977) (Fourteenth Amendment imposes self-executing limits on states; Congress subject to essentially identical limits under Fifth Amendment); $c f$. Bivens v. Six Unknown Agents, 403 U.S. 388, 396-97 (1971) (implying right to sue for money damages under Fourth Amendment).

77. If the right-holder did not want his right enforced, his preference would negate the presumption that the right provided him with highly valued satisfaction.

78. The executive's superior fact-finding capacity results from the location of various law enforcement and investigatory agencies within the executive branch. Of these, probably the most important is the Department of Justice. Cf. O. Fiss, The Civil Rights InjuncTION 22 (1978) (Justice Department may be only agency with sufficient evidence-gathering resources to determine when on-going patterns of rights violations require injunctive remedies).

79. See Singleton v. Wulff, 428 U.S. 106, 113-14 (1976) (plurality opinion of Blackmun, J.). In Singleton, Blackmun spoke for a majority of the Court in sections I, IIA, and III of his opinion. Section IIB of the opinion was accepted by a plurality, and its analysis also adopted by Justice Stevens, who concurred, on the particular facts of the case. Id. at 121-22 (Stevens, J., concurring).

80. The Latin phrase refers to the "right of a third [person]." In the standard jus tertii case, a plaintiff, who has himself been injured, seeks to invoke the rights of another party not before the court. See, e.g., Craig v. Boren, 429 U.S. 190 (1976) (licensed vendor of beer, economically injured by Oklahoma statute prohibiting sales to 18 - to 20 year-old males but allowing sales to 18 - to 20-year-old females, granted standing to assert equal protection rights of males). A jus tertii action by the United States would differ somewhat from this model, because the injury to the United States would consist of the injury to the persons whose rights the government sought to claim. Government suits to 


\section{Standing}

Jus tertii questions arise in cases in which one party, who already enjoys standing based on injury-in-fact, seeks a different, further kind of standing to assert the rights of some third party not before the court. ${ }^{81}$ Ordinarily, as a matter of policy, the Supreme Court will not allow a litigant to claim third-party rights. ${ }^{82}$

But the Court has recognized that the assumption that a citizen is the best judge of his own interests-and therefore the most appropriate advocate of those interests-should be subject to an important qualification. When "there is some genuine obstacle" 83 to the third party's assertion of his own rights, the justifications for barring assertions of jus tertii disappear. ${ }^{84}$ In such cases the courts will uphold the standing of one party to assert the rights of another.

When the United States sues to redress injuries to private parties, the rights it asserts belong not to the United States as an entity but to the persons it seeks to protect. Public interest suits to protect individual rights thus fall under the jus tertii doctrine and should be subject to its rules. Even though the executive might decide that the public interest would be served by bringing suit in a certain instance, courts should not permit nonstatutory standing when there is no reason to believe that the aggrieved party could not adequately protect his own interests. ${ }^{85}$

protect citizen interests would, however, present a close analogue to a case in which the Supreme Court applied a jus tertii analysis before allowing an organization to claim the rights of its members. See NAACP v. Alabama ex rel. Patterson, 357 U.S. 449, 458-60 (1957).

81. See Singleton v. Wulff, 428 U.S. 106, 112 (1976) (distinguishing the two types of standing); Flast v. Cohen, 392 U.S. 83, 99 n.20 (1968). See generally Sedler, Standing to Assert Constitutional Jus Tertii in the Supreme Court, 71 YALE L.J. 599 (1962); Note, Standing to Assert Constitutional Jus Tertii, 88 Harv. L. Rev. 423 (1974).

82. See Flast v. Cohen, 392 U.S. 83, 99 n.20 (1968); Barrows v. Jackson, 346 U.S. 249, 255 (1953).

83. Singleton v. Wulff, 428 U.S. 106, 116 (1976) (plurality opinion of Blackmun, J.).

84. See Craig v. Boren, 429 U.S. 190, 195 (1976) (plaintiff should be allowed to assert "rights of third parties that would be "diluted or adversely affected" " if claim were disallowed); Singleton v. Wulff, 428 U.S. 106, 116 (1976) (plurality opinion of Blackmun, J.) (third-party claims acceptable if primary party faces barrier to litigation).

85. The test should turn on a judgment of fact: Is there a practical or legal barrier to action sufficiently great to cancel the presumption that anyone who attaches significant value to his rights will act to defend them? See Singleton v. Wulff, 428 U.S. 106, 116 (1976) (plurality opinion of Blackmun, J.) (upholding physicians' standing to assert patients' constitutional rights in attacking statute denying welfare funds for abortions, because, although women could have brought suits, women's actions impeded by possible desire to protect privacy). In the absence of adequate legal aid, economic deprivation could cancel the presumption in at least some cases. Where legal aid would be available, but where a rights-holder lacked the awareness to seek it, the individual's failure of initiative would not indicate that he experienced no injury. 


\section{Separation of Powers: Authority to Seek a Remedy}

In challenging executive authority to bring nonstatutory suits, some courts have confused the distinction between the right to urge a claim in court and the power to legislate a right to relief on the claim presented. The scope of the executive's claimed authority must, therefore, be properly defined before substantive analysis can begin. Justice Jackson's concurring opinion in Youngstown Sheet o Tube Co. v. Sawyer ${ }^{80}$ formulates a conceptual model within which separationof-powers questions can be addressed. Modified to accommodate differences among constitutionally distinct classes of cases, Jackson's model suggests that the President possesses independent authority to bring suit to protect national security interests and to vindicate constitutional rights.

\section{A. Asking the Right Question}

Opponents of nonstatutory suits have sometimes characterized the separation-of-powers issue as one about the propriety of the executive legislating his own "cause of action," 87 in the sense of creating a right to relief. ${ }^{88}$ This formulation reflects a fundamental misunderstanding. Standing is only a threshold requirement of the existence of a right to relief. Having surmounted the standing test, the executive still must persuade the court that it possesses a right to the remedy sought. ${ }^{89}$ When no cognizable source of law establishes the "right"

86. See 343 U.S. 579, 634-55 (1952) (Jackson, J., concurring).

87. The term "cause of action" carries a variety of meanings. Davis v. Passman, 99 S. Ct. 2264, 2272-74 (1979); United States v. Memphis Cotton Oil Co., 288 U.S. 62, 67-69 (1933). Last Term, the Supreme Court stated that "cause of action is a question of whether a particular plaintiff is a member of the class of litigants that may, as a matter of law, appropriately invoke the power of the court." Davis v. Passman, 99 S. Ct. 2264, 2274 n.18 (1979). According to more traditional usage, the phrase refers to the alleged invasion of "recognized legal rights" upon which a litigant bases his claim for relief. Larson v. Domestic \& Foreign Commerce Corp., 337 U.S. 682, 693 (1949); see Davis v. Passman, 99 S. Ct. 2264, 2273 (1979).

88. See Note, Constitutional Law-United States Government's Standing to Sue-A New Approach to Legal Assistance for Ghetto Residents or an Invitation to Execulive Lawmaking? 17 WAYNE L. REv. 1287 (1971) (criticizing United States v. Brand Jewelers, Inc., 318 F. Supp. 1293 (S.D.N.Y. 1970), which granted United States standing to assert Fourteenth Amendment rights of ghetto residents); cf. New Xork Times Co. v. United States, 403 U.S. 713, 742 (1971) (Marshall, J., concurring) (Constitution "did not provide for government by injunction" in which courts and executive "can 'make law' without regard to the action of Congress"); United States $v$. Solomon, 563 F.2d 1121, 1128.29 (4th Cir. 1977) (suggesting President "make[s] law" whenever he assumes power to act in absence of explicit constitutional or legislative authorization).

89. The distinction between a right to standing in court and a substantive right to a certain decision by the court is illustrated by New York Times Co. v. United States, 403 U.S. 713 (1971). In the Times case, the Supreme Court held that the executive had 
asserted, a court must rule that the complaint by the United States fails to state a claim on which relief can be granted and therefore must dismiss the action. Such a dismissal, which can occur after full argument on the merits, does not call into question the initial determination of United States standing. ${ }^{00}$ Correspondingly, a grant of standing establishes neither an underlying legal right nor the authority to create one. It always remains to the courts to determine whether the alleged right exists.

\section{B. Enforcing Rights and Creating Remedies: A Model for Analysis}

Because the national executive does not "make law" by bringing a nonstatutory suit, the question of which branch determines when the United States should sue is a question not about legislating sub-

no right to an injunction against publication of the Pentagon Papers. But whether there was a right to a nonstatutory injunction remained unclear until the Supreme Court had implicitly acknowledged the standing of the national executive by considering its arguments on the merits and adjudicating its claim for relief. As Professor Bickel recognized in his brief for the Times, "the Government's standing to come into court" was "a wholly separate matter from the issue of inherent executive authority, without the aid of legislation, to formulate and establish substantive rules of law." Brief for Petitioner, 403 U.S. 713 (1971), at 32; cf. Duke Power Co. v. Carolina Environmental Study Group, Inc., 438 U.S. 59, 70.72 (1978) (distinguishing standing from subject matter jurisdiction); Baker v. Carr, 369 U.S. 186, 204.09 (1962) (distinguishing standing from justiciability).

90. This is so even though the government's standing posture differs from that of a private litigant. In order to satisfy the usual requirements of standing, a plaintiff must allege injury to some interest of his own. See pp. 124-25 supra. After reviewing the pleadings or considering the claim at trial, a court may find that the asserted interest is not legally protected. Nonetheless, standing could still be based on the "real" injury to the plaintiff, even though that injury did not reach a "legal" interest.

The government's position is arguably somewhat different. When the United States claims nonstatutory standing on the basis of injury to a citizen's constitutionally protected interest, the injury on which it bases its standing depends on the existence of the citizen's claimed legal right. If the court determines that the claimed legal right does not exist, or that it has not in fact been violated, the alleged injury to the public interest will not have occurred, or at least will not be verifiable. Nevertheless, the nonexistence of an asserted legal interest of the United States or the invalidity of its cause of action is better analyzed as a decision on the merits than as a retrospective determination that the United States lacked standing from the outset.

The Supreme Court has ruled that an allegation of injury to the plaintiff is a constitutional requirement of standing. Warth v. Seldin, 422 U.S. 490, 501 (1975). The Court also has determined that Congress can confer standing by legislative grant, even where no "real" injury to the United States exists. See United States v. Raines, 362 U.S. 17, 27 (1960). In order to reconcile these holdings, legislative conferrals of United States standing must be analyzed as the creation of legal governmental interests in not having citizen rights violated; otherwise there would be no injury to the government. Yet the govern. ment, when it brings a suit, cannot always know that citizen rights have in fact been abridged; questions of law and fact may remain to be determined by the court. For an allegation of injury to satisfy the standing requirement, standing must therefore be viewed as a doctrine that is concerned with the propriety of allowing a party to bring suit on the supposition that the facts are all as alleged. 
stantive legal rights but about enforcing them. ${ }^{91}$ Decisions involving law enforcement ordinarily fall within the Article II mandate of the executive branch. ${ }^{92}$ But nonstatutory suits also represent a means of remedying rights violations, and the creation of remedies is characteristically a legislative, rather than an executive, function. Nonstatutory suits therefore lie close to the penumbras of both the executive and congressional spheres. ${ }^{93}$

Justice Jackson's concurring opinion in the Youngstown case suggests a model for defining the limits of executive authority and identifying the powers within those limits. ${ }^{9 t}$ Jackson's opinion grouped executive claims to authority into three broad classes. According to his analysis, the President's constitutional power attains its maximum when he acts pursuant to the express or implied will of Congress. ${ }^{95}$ When he acts in the absence of either a congressional grant or denial of statutory power, the executive moves in a "zone of twilight," in which the constitutionality of his actions depends on the "imperatives of events and contemporary imponderables."90 Presidential authority declines to its "lowest ebb" when the executive undertakes measures incompatible with the express or implied congressional will. ${ }^{97}$

Within Jackson's scheme, many presidential assertions of authority

91. Youngstown Sheet \& Tube Co. v. Sawyer, 343 U.S. 579 (1952), has been relied upon in recent opinions denying United States standing in order to support the proposition that the executive must not be permitted to engage in lawmaking. See New York Times Co. v. United States, 403 U.S. 713, $741-42$ (1971) (Marshall, J., concurring); United States v. Solomon, 563 F.2d 1121, 1129 (4th Cir. 1977). Not only does the concern about executive lawmaking itself rest on a misconception, see pp. 136-37 supra, but the reliance on Youngstown also is misplaced. In Youngstown, a case holding that the President had no legal right to seize and operate the nation's steel mills to avert the injurious consequences of a threatened strike, the Court had no occasion to consider issues of standing. Executive officers appeared not as plaintiffs but as defendants. There was no inquiry into the possible existence of injury to the United States, and the question of the President's authority to claim rights and to have his claims adjudicated was not before the Court. The Youngstown determination that the President lacked a specific legal right did not imply that he lacked authority to claim other substantive rights of the United States.

92. See U.S. Const. art. II, $\$ 3$ (investing executive with responsibility to "take care that the laws be faithfully executed"). The article's conferral of executive power also has been interpreted as a substantive grant of authority, at least some of which cannot be removed by Congress. See Myers v. United States, 272 U.S. 52 (1926) (statutory limitation on President's power to discharge postmasters unconstitutionally infringes article II executive powers).

93. Cf. H. HART, The Concept of LAw 119 (1961) (penumbras of doubt inevitable in bringing particular situations under general rules).

94. See Youngstown Sheet \& Tube Co. v. Sawyer, 343 U.S. 579, 635-40 (Jackson, J., concurring).

95. Id. at $635-37$.

96. Id. at 637 .

97. Id. at 637-38. 
to claim standing would plainly fall in the zone of twilight. If so, the invocation of a cognizable public interest would provide a strong justification for upholding executive authority to sue. This justification would be weakened only when Congress had provided alternative enforcement mechanisms for the right involved. Congressional provision of remedies other than injunctions obtained on the executive's initiative could, at least in some instances, signal Congress's preference for use of those remedies, ${ }^{98}$ and thus remove a claim of nonstatutory standing from Jackson's second category to his third, that of presumptive invalidity.

\section{Three Classes of Cases}

Justice Jackson's model presupposes an undifferentiated view of the relationship between the executive and legislative branches. Even within the twilight zone of executive action, however, the Constitution creates a mosaic of greater and lesser institutional responsibilities and competences. Questions of authority to apply for judicial relief arise in the same three contexts as questions of competence to identify interests: (I) claims under statutes and the commerce clause; (2) suits to protect the national security; and (3) actions to enforce constitutional rights. The three categories present different constitutional issues.

\section{Statutes and the Commerce Clause}

When Congress enacts legislation, it is presumed that the House and Senate have considered the subject closely and have created the package of rights and remedies that they think most desirable. The courts therefore have held that legislative intent, explicit or implicit, should guide judicial decisions about the rights of action to be implied from federal statutes. ${ }^{99}$ By analogous reasoning, both implicit

98. Under 42 U.S.C. $\$ 1983$ (1976), individuals can bring suit for injunctive or other relief for violations of their civil rights by state officials. It can thus be argued that Congress has shown that it prefers this alternative private remedy to a nonstatutory suit brought by the United States to redress violations of individual rights by these officials. See 1977 B.Y.U. L. Rev. 474, 484-87; cf. National R.R. Passenger Corp. v. National Ass'n of R.R. Passengers, 414 U.S. 453, 458 (1974) (invoking maxim "expressio unius est exclusio alterius" to infer congressional intent in suit seeking to imply private cause of action under statute authorizing Attorney General to represent public rights). But see McMahon \&: Rodos, Judicial Implication of Private Causes of Action: Reappraisal and Retrenchment, 80 Dıck. L. REv. 167, 188-90 (1976) (criticizing use of "expressio unitu" in National Railroad Passenger case).

99. See Cort v. Ash, 422 U.S. 66, 78 (1975); National R.R. Passenger Corp. v. National Ass'n of R.R. Passengers, 414 U.S. 453, 458 (1974). 
and explicit evidence of congressional intent also should be important in determining whether the executive may claim standing to enforce rights established by legislative action. ${ }^{100}$

Because the commerce power resides in Congress, standing under the commerce clause should be subject to the same "explicit or implicit" measure of congressional intent as suits under statutes. Under this standard, congressional preference for an alternative remedy would remove commerce clause actions from the twilight area and locate executive claims to standing in the third category of presumptive invalidity. ${ }^{101}$

\section{National Security}

Claims to standing under the executive's national security power call for a different type of analysis. The location of extensive national security powers in the executive brings national security claims closer to the executive side than to the legislative side of the zone of twilight. Under the Constitution, the President is delegated such primary foreign affairs responsibilities as making treaties and nominating ambassadors. ${ }^{102}$ Congress is entrusted with the secondary functions of ratification and confirmation. ${ }^{103}$ Moreover, as courts have recognized repeatedly, the executive branch, as a matter of practical necessity, must take the leading role in developing the nation's foreign

100. Courts have developed a number of methods of ascertaining intent. See note 11 supra (listing criteria enunciated in Cort v. Ash, 422 U.S. 66, 78-79 (1975)). Although formulated as indices of the legislature's intent with regard to implication of rights of action, the Cort criteria could function with equal effectiveness if applied to the standing question. If the legislative history were clear, there would, of course, be no need for such a sophisticated test. See Albert, Standing to Challenge Administrative Action: An Inadequate Surrogate for Claim for Relief, 83 YALE L.J. 425, 452-56 (1974) (intent typically unclear under intricate regulatory statutes); cf. Wellington, Common Law Rules and Constitutional Double Standards: Some Notes on Adjudication, 83 YALE L.J. 221, 262-63 (1973) (court should decide as legislature would have decided if it had addressed issue).

10I. This conclusion suggests that the commerce clause did not provide a sound basis for the executive suit in In re Debs, 158 U.S. 564 (1895). Nonetheless, by enacting the Sherman Act under its general authority to regulate commerce, Congress provided a statutory basis from which authorization of the suit could be implied. Cases in which the government has been allowed to sue under the commerce clause but without explicit statutory authority in order to enjoin violations of individual rights, see, e.g., United States v. City of Shreveport, 210 F. Supp. 36 (W.D. La. 1962), aff'd, 316 F.2d 928 (5th Cir. 1963); United States v. United States Klans, 194 F. Supp. 897 (M.D. Ala. 1961), similarly seem to be wrongly reasoned but rightly decided. A correct, alternative analysis would be to disregard the commerce clause and categorize such actions as suits to enforce constitutional rights. See pp. 142-43 infra (asserting executive's authority even in absence of statute to sue to enforce constitutional rights).

102. U.S. Const. art. II, § 2.

103. Id. 
and national security policies. ${ }^{104}$ Thus, in the area of national security, there should be no objection to executive authority to seek to protect the public interest by initiating judicial proceedings.

This analysis would not dismiss the relevance of congressional intent in determining the limits of the government's substantive rights. Congressional provision of alternative remedies might affect a court's decision on the merits of the executive's claim to relief. ${ }^{105}$ Furthermore, Congress could always negate executive standing by enacting an explicit statute of denial. However, in the area of national security, a clear statement of legislative policy should be required to nullify the President's presumptive authority. ${ }^{106}$ In light of the vagaries of the legislative process, congressional failure to enact an authorizing statute should not be a determinative indicator of legislative intent. ${ }^{107}$

104. See, e.g., United States v. Pink, 315 U.S. 203, 229 (1942) (President, without consent of Senate, has authority to compromise outstanding claims of United States citizens against Soviet government; "delicate problems of foreign relations" require recognition of exccutive authority in area); United States v. Belmont, 301 U.S. 324, 330-31 (1937) (executive has authority to speak as "sole organ" of United States government in negotiating international compact).

105. This is a question about the existence of substantive legal rights for which Youngstown Sheet \& Tube Co. v. Sawyer, 343 U.S. 579 (1952), does provide authority. Of the five justices who joined Justice Black's opinion of the Court, four found decisive the negative implications they drew from the Labor Management Relations Act of 1947, which allowed the executive to apply for a temporary injunction against a strike. See 343 U.S. at 599.610 (Frankfurter, J., concurring), $639-40$ (Jackson, J., concurring), 656-57 (Burton, J., concurring), 662-66 (Clark, J., concurring).

106. Professor Black has reached a similar conclusion in his analysis of the Supreme Court's reasoning in Youngstown Sheet \& Tube Co. v. Sawyer, 343 U.S. 579 (1952):

The troublesome question in the Youngstown decision was whether the Supreme

Court should have picked up ... [a congressional intent to forbid seizure] from

mere negative implication; Congress had never actually said, "No seizure." It may

be reasonable to require that congressional negative on presidential acts affecting the security of the nation be definitive and express.

C. Black, Perspectives in Constitutional Law 62 (1970 ed.).

107. The Supreme Court recognized the significance of this uncertainty in United States v. California, 332 U.S. 19 (1947), a suit to vindicate federal ownership of offshore lands. Bills to authorize the suit had twice failed to pass. Id. at 28 . Indeed, both houses had adopted a joint resolution, vetoed by the President, that quitclaimed the lands in question. Id. Nonetheless, the Court upheld the executive's authority to bring suit. The exccutive, the Court reasoned, possessed a general responsibility to determine which interests to assert in the courts and to act accordingly. Although congressional power to limit this authority was undisputed, the Court required "an exercise of the constitutional power of Congress," id., through legislation, to strip the executive of "the authority and duty to protect the Government's interests through the courts," id. at 27-28. The Court's opinion seemed to place weight on a statute that authorized the Attorney General to conduct any litigation in which the United States "is interested." See id. at 26-27. But that statute, like the current provisions of 28 U.S.C. $\$ \S 516-18$ (1976), merely established that any suit properly brought by the United States may be conducted by the Justice Department. See United States v. Solomon, 563 F.2d 1121, 1124 


\section{Cases to Enforce Constitutional Rights}

When Congress enacts a statute, thereby creating legal rights, the courts naturally have held that congressional intent is crucial in determining to whom rights of action extend. ${ }^{108}$ Several courts have extended this reasoning to the question of executive authority to enforce constitutional rights. ${ }^{109}$ In the absence of an affirmative congressional act, they have held that Congress intended to withhold the enforcement mechanism of government suits, and that this negative implication of congressional intent determines the question.

This analysis overlooks the distinction between enforcing rights derived from statutes and protecting those arising under the Constitution. Because of the Constitution's status as higher law, the Supreme Court has held that congressional failure to act should not restrict the implication of constitutional remedies. ${ }^{110}$ Rights of action are presumed to exist in the absence of countervailing factors, such as an "explicit congressional declaration" to the contrary.111

Similar reasoning should apply in determining whether congressional failure to authorize executive action removes a claim of standing to enforce constitutional provisions from the second to the third of Jackson's categories. Because constitutional rights and remedies arise independently of congressional action, the executive's claim of inherent authority to enforce the law is not confronted with a strong

(4th Cir. 1977); United States v. Daniel, Urbahn, Seelye and Fuller, 357 F. Supp. 853, $857-58$ (N.D. Ill. 1973). The Court's reasoning in United States $v$. California would seem to apply $a$ fortiori when the President sceks standing to enforce rights arising independently of Congress from the Constitution of the United States.

108. See, e.g., Cort v. Ash, 422 U.S. 66, 78 (1975); National R.R. Passenger Corp. v. National Ass'n of R.R. Passengers, 414 U.S. 453, 458 (1974); cf. p. 132 supra (discussing general congressional competence to weigh competing interests in determining public interest).

109. See, e.g., United States v. Solomon, 563 F.2d 1121, 1125, 1128-29 (4th Cir. 1977);

United States v. Madison County Bd. of Educ., 219 F. Supp. 60, 61 (N.D. Ala. 1963), aff'd on other grounds, 326 F.2d 237 (5th Cir.), cert. denied, 379 U.S. 929 (1964).

110. Davis v. Passman, 99 S. Ct. 2264, $2277-78$ (1979); Bivens v. Six Unknown Agents, 403 U.S. $388,395-97$ (1970).

111. Davis v. Passman, 99 S. Ct. 2264, 2277 (1979) (quoting Bivens v. Six Unknown Agents, 403 U.S. 388, 396-97 (1971)). Bivens, which is the leading case on this subject, raised an issue about the implication of a right of action, rather than about standing. The remedy problem therefore presented a different aspect in that case than it would in suits by the United States to enforce individual rights. The form of remedy the United States has sought in nonstatutory suits to protect citizen rights, injunctive relief, is routinely granted in constitutional cases, even in the absence of statutory authorization. See Bell v. Hood, 327 U.S. 678, 684 (1946); Hill, Constitutional Remedies, 69 ColuM. L. REV. $1109,1110-11$ (1969). The problem in government cases thus concerns the means of securing the remedy authorized, namely a suit by the executive, rather than the form of relief, as in Bivens. 


\section{Standing}

congressional claim of control over rights enforcement mechanisms. ${ }^{112}$ Although Congress could explicitly deny standing to the United States or any other party, a denial that limits the enforcement of constitutional rights should require an explicit congressional declaration.

112. The ten amendments constituting the Bill of Rights refer to Congress only to create private rights against congressional action. See U.S. CoNsT. amends. I-X. The argument for congressional authority in authorizing enforcement might seem particularly strong under the Fourteenth Amendment, because of the provision in $\S 5$ that Congress shall have power to "enforce this article by appropriate legislation." But this section, which confers authority to create new mechanisms of enforcement, does not imply the nonexistence of other mechanisms. Moreover, $\S 5$ has been construed as a grant of congressional authority only to expand, and not to diminish, protections arising under the substantive provisions of the Amendment. See note 76 supra. 